\title{
Photochemical formation of biologically available nitrogen from dissolved humic substances in coastal marine systems
}

\author{
Karen L. Bushaw-Newton*, Mary Ann Moran** \\ Department of Marine Sciences and Institute of Ecology, University of Georgia, Athens, Georgia 30602-3636, USA
}

\begin{abstract}
The photochemical conversion of the nitrogen fraction of dissolved humic substances into more biologically available compounds was studied in 2 estuarine sites in the southeastern U.S. Marine humic substances were isolated using an XAD-8 resin and used in bacterial bioassays and chemical studies. The bioassays demonstrated that humic substances irradiated with natural sunlight supported enhanced bacterial growth, measured as cell accumulation and protein production, due to increased availability of both the carbon and nitrogen components. Chemical analyses demonstrated the photoproduction of ammonium and dissolved primary amines from the coastal humic substances. The total biologically available nitrogen (ammonium, dissolved primary amines, and other unidentified compounds) formed during a day-long irradiation at natural solar radiation levels accounted for about $6 \%$ of the original nitrogen associated with the humic substances. Photochemical modification of marine humic substances may provide a source of labile nitrogen to estuarine and coastal ecosystems that has not previously been considered.
\end{abstract}

KEY WORDS: Dissolved organic matter - Dissolved organic nitrogen - Humic substances - Photodegradation · Ammonium - Dissolved primary amines - Bacterial secondary production

\section{INTRODUCTION}

Humic substances are an important component of dissolved organic matter (DOM) in estuaries and nearshore marine waters, where they can account for up to one-quarter of the total DOM (Thurman 1985). Coastal humic substances are a mixture of compounds derived from both marine sources (formed in situ by biological and chemical processes; Bronk et al. 1998) and terrestrial sources (derived from coastal marsh and riverine exports; Moran et al. 1991). Humic substances are known to have extremely long average residence times in the marine environment (Bauer et al. 1992), although recent studies indicate that at least a portion

\footnotetext{
- Present address: National Oceanic and Atmospheric Administration, NOS-COP, 1315 East-West Highway, SSMC3 (Room 9700), Silver Spring, Maryland 20910, USA

- Addressee for correspondence.

E-mail:mmoran@arches.uga.edu
}

of marine humic substances can cycle on relatively short (days to weeks) time scales (Carlsson \& Granéli 1993, Moran \& Hodson 1994). Current evidence suggests that terrestrially derived humic substances do not accumulate significantly in the ocean (Meyers-Shulte \& Hedges 1986), despite the fact that these compounds are considered to be among the most biologically refractory components of DOM.

The mechanisms by which dissolved humic substances are removed from the DOM pool in planktonic marine systems are known to include both biological and photochemical processes. Marine bacterioplankton decompose components of humic substances and route a portion of the carbon to higher trophic levels (Moran \& Hodson 1990, 1994, Carlsson et al. 1995). Photochemical processes also break down dissolved humic substances in seawater, resulting in the formation of carbon gases and low molecular weight organic compounds that can be readily utilized by bacterioplankton (Moran \& Zepp 1997). 
Most previous studies investigating the fate of dissolved humic substances in marine environments have focused only on the carbon component. More recently, the nitrogen component of humic substances has been found to be degraded in coastal waters, with both biological (Carlsson \& Granéli 1993, Carlsson et al. 1993, Seitzinger \& Sanders 1997) and photochemical (Bushaw et al. 1996) mechanisms implicated. Photochemical degradation of humic substances has been found to result in the release of amino acids (Amador et al. 1989, Jørgensen et al. 1998), the formation of free ammonium (Bushaw et al. 1996, Gardner et al. 1998), and the release of combined amino acids and possibly urea (Jørgensen et al. 1998).

Here we report studies of the formation of labile nitrogen photoproducts from humic substances collected from 2 coastal sites in the southeastern U.S. As is typical of many coastal systems (Seitzinger \& Sanders 1997 ), 50 to $80 \%$ of the nitrogen exported to the southeastern U.S. is in the form of dissolved organic nitrogen (DON) (Alberts \& Filip 1994), of which a significant fraction is humic substances. Previous studies have shown that up to $75 \%$ of the nearshore humic substances in this region are of terrestrial origin (Moran \& Hodson 1994).

\section{METHODS}

Surface water was collected from the Skidaway River Estuary at the dock of the Skidaway Institute of Oceanography $\left(32^{\circ} \mathrm{N}, 81^{\circ} \mathrm{W}\right)$ in August 1995 (25\% salinity) and February 1996 (19\%) and from the Satilla River Estuary $\left(31^{\circ} \mathrm{N}, 81.5^{\circ} \mathrm{W}\right)$ in October $1996(11 \%)$. Within $24 \mathrm{~h}$ of collection, the water was sequentially filtered through $0.6 \mu \mathrm{m}$ pore-size glass fiber and $0.2 \mu \mathrm{m}$ pore-size polycarbonate filters to remove particulates, and was acidified to $\mathrm{pH} 2$. Humic substances were isolated by passing the acidified sample through an Amberlite XAD-8 resin, and then eluting the organic matter retained on the resin with $0.1 \mathrm{~N} \mathrm{NaOH}$ (Leenheer 1981, Aiken 1985). The concentrated humic substances samples were stored at $4^{\circ} \mathrm{C}$.

Biological studies. The concentrated humic substances from the August and February Skidaway River samples were reconstituted in an artificial seawater medium (Harrison et al. 1980). In order to ensure low background nitrogen and phosphorus concentrations, each chemical used in the artificial seawater was baked at either 100 or $500^{\circ} \mathrm{C}$ before dissolving at 2.5 times $(2.5 \times)$ final concentration in deionized water that had been cartridge-filtered to remove organic contaminants (Solution 2000 Water Purification System, Solution Consultants, Inc.). The $2.5 \times$ stock solution was boiled for $3 \mathrm{~h}$ and then brought to $1 \times(25 \%$ salinity $)$ with additional deionized water. Humic substances were added to the artificial seawater matrix at approximately $2.8 \times$ the ambient concentration at the time of water collection. For the irradiated treatments, one half of each sample was placed in a 21 round-bottom quartz flask and exposed to full sunlight from 09:00 to 16:00 h ( 7 h) on January 25, 1996 (for the August humic substances) or April 3, 1996 (for the February humic substances). For the dark treatments, the other half of each sample was treated identically except the flask was wrapped in aluminum foil. All flasks were placed in an ice water bath so that temperatures inside the flasks never exceeded $10^{\circ} \mathrm{C}$, and flasks were swirled periodically during the irradiation. Exposure to UV light in the 286 to $363 \mathrm{~nm}$ range during the $7 \mathrm{~h}$ incubation was $9.4 \mathrm{~W} \mathrm{~m}^{2}$ for the August sample (Brewer Mark IV spectroradiometer, $0.5 \mathrm{~nm}$ resolution); UV data were not available for the February sample.

Following irradiation, replicate $250 \mathrm{ml}$ flasks were filled with $150 \mathrm{ml}$ of the reconstituted humic substances and assigned to 1 of 4 nutrient amendments ( 3 flasks treatment ${ }^{-1}$ ): no amendment (Control), an amendment of $16 \mu \mathrm{M} \mathrm{N}$ as $\mathrm{NH}_{4} \mathrm{NO}_{3}(\mathrm{~N})$, an amendment of $1 \mu \mathrm{M}$ P as $\mathrm{PO}_{4}(\mathrm{P})$, or amendments of both $\mathrm{N}$ and $\mathrm{P}(\mathrm{N}+\mathrm{P})$. A bacterial inoculum was made by concentrating the natural bacterioplankton community from whole water obtained at the same site as the original sample. The water was pre-filtered through a $1.0 \mu \mathrm{m}$ pore-size membrane filter and bacteria were then concentrated over a $0.2 \mu \mathrm{m}$ pore-size filter. The bacterial concentrate was added to the flasks, giving initial cell densities of $3.2 \times 10^{4}$ (August humic substances) and $2.2 \times 10^{4}$ (February humic substances) cells $\mathrm{ml}^{-1}(\mathrm{n}=24)$. The flasks were sealed with foil tops and incubated in the dark for $96 \mathrm{~h}$ (August humic substances) or $120 \mathrm{~h}$ (February humic substances) at $100 \mathrm{rpm}$.

Bacterial growth at the expense of the humic substances was measured as net increases in bacterial numbers and from instantaneous rates of incorporation of ${ }^{3} \mathrm{H}$-leucine into bacterial protein at $0,24,48,96$, and $120 \mathrm{~h}$ after inoculation. For bacterial number measurements, $10 \mathrm{ml}$ subsamples were removed from each flask at each time point, preserved with $0.6 \mathrm{ml}$ boratebuffered formalin, and counted via epifluorescence microscopy after staining with $0.01 \%$ Acridine Orange (Hobbie et al. 1977). Bacteria were counted in 10 fields slide $^{-1}$, with approximately 30 bacteria field $^{-1}$. Carbon utilization was calculated assuming a $30 \%$ carbon conversion efficiency (Moran \& Hodson 1990) and $33 \mathrm{fg} \mathrm{C}$ bacterial cell ${ }^{-1}$ (Tuomi et al. 1995). For bacterial production measurements, samples were incubated with ${ }^{3} \mathrm{H}$-leucine $(20 \mathrm{nM}$ final concentration, $158 \mathrm{mCi}$ mmol ${ }^{1}$ ) following the method of Smith \& Azam (1992).

Chemical studies. The August and February Skidaway River humic substances samples used in the bio- 
logical studies were also used for chemical studies of photoproduct formation, along with another humic substances sample from the Satilla River Estuary reconstituted at approximately $2.8 \times$ ambient concentration. In addition, the February Skidaway River humic substances were reconstituted at a higher concentration (28x ambient) to allow analytical detection of nitrogenous photoproducts that might be produced at low rates. Irradiation pratocol for the two $2.8 \times$ Skidaway River samples was described above. For the Satilla River Estuary sample and the $28 \times$ February Skidaway River sample, humic substance solutions were filtered to ensure sterility $(0.2 \mu \mathrm{m}$ pore-size filter), placed in $25 \mathrm{ml}$ quartz tubes with silicone stoppers, wrapped in foil (dark treatment) or left unwrapped (irradiated treatment), and incubated in ice water baths in full sunlight for $7 \mathrm{~h}$ on October 11, 1996 (28x February Skidaway River) or November 11, 1996 (2.8x Satilla River Estuary). UV irradiation (286 to $363 \mathrm{~nm}$ ) was $6.8 \mathrm{~W} \mathrm{~m}^{-2}$ for the February Skidaway River sample and $4.1 \mathrm{~W} \mathrm{~m}^{-2}$ for the Satilla sample.

Analyses. Subsamples for analyses of dissolved organic carbon (DOC), absorbance, and inorganic and organic nitrogen species were removed from all treatments before and after irradiation. DOC concentrations were determined by high temperature catalytic oxidation using a Shimadzu TOC-5000 carbon analyzer. Initial DOC concentrations in the samples ranged from $232 \mu \mathrm{M}(2.8 \times$ Skidaway River, February) to $2400 \mu \mathrm{M}(2.8 \times$ Satilla River Estuary) (Table 1). Light absorbance by the humic substances concentrates was measured in quartz cuvettes at $350 \mathrm{~nm}$, a wavelength at which absorption is dominated by humic substances (Zepp \& Schlotzhauer 1981). Absorbance coefficients $\left(a_{350}\right)$ were calculated according to the formula of Miller \& Zepp (1995) and used to normalize photoproduct formation for differences in light screening and absorptivity among samples (Table 1).

Subsamples for nitrogen analyses were stored in acid-washed HDPE bottles at $-20^{\circ} \mathrm{C}$ until analysis. Concentrated $\mathrm{HCl}(6 \mathrm{~N})$ was used to lower the $\mathrm{pH}$ of samples for primary amine analysis to $\mathrm{pH} 2$. Ammonium concentrations were measured using the Koroleff method (Grasshoff et al. 1983). Bulk primary amine concentrations (which includes amino acids, peptides, and polypeptides) were measured using the o-pthaldialdehyde (OPA) technique with a Turner Designs TD700 fluorometer (Parsons et al. 1992). Fluorescence of each sample (342 $\mathrm{nm}$ excitation, $452 \mathrm{~nm}$ emission) was measured before and after the addition of the OPA reagent and bulk primary amine concentrations were calculated using corrections for natural fluorescence of the water and ammonium fluorescence.

DON was determined by subtracting the inorganic nitrogen species from the concentration of total dissolved nitrogen (TDN). Samples from the Skidaway River were measured using the UV oxidation method (Armstrong \& Tibbitts 1968), while the sample from the Satilla River Estuary was measured using the persulfate oxidation method (Parsons et al. 1992). For the Skidaway River samples, a $20 \mathrm{ml}$ volume was pipetted into a quartz tube with $200 \mu \mathrm{l}$ of $30 \% \mathrm{H}_{2} \mathrm{O}_{2}$, sealed in the tube, and exposed to a UV lamp for $18 \mathrm{~h}$. For the Satilla River Estuary sample, a $40 \mathrm{ml}$ volume of sample was placed into a $125 \mathrm{ml}$ Teflon bottle with $6.0 \mathrm{ml}$ of oxidizing reagent $\left(6.0 \mathrm{~g}\right.$ of $\mathrm{K}_{2} \mathrm{~S}_{2} \mathrm{O}_{8}$ in $100 \mathrm{ml}$ of $\left.1.5 \mathrm{M} \mathrm{NaOH}\right)$ and autoclaved for $30 \mathrm{~min}$ and then acidified and buffered (Parsons et al. 1992). After the oxidation pro-

Table 1 Formation of labile $\mathrm{N}$ photoproducts and elemental composition of coastal humic substances. Standard errors are in parentheses. nd: not detected

\begin{tabular}{|c|c|c|c|c|c|c|c|}
\hline Photoproduct/sample & $\begin{array}{c}\text { Sample } \\
\text { date }\end{array}$ & $\begin{array}{l}\text { Production } \\
\text { rate } \\
\left(\mathrm{nM} \mathrm{h}^{-1}\right)\end{array}$ & $\begin{array}{l}\text { Normalized } \\
\text { production rate } \\
\left(\mathrm{nM} \mathrm{m} \mathrm{h}^{-1}\right)\end{array}$ & $\begin{array}{l}{[D O C]} \\
(\mu M C)\end{array}$ & $\begin{array}{l}{[\mathrm{DON}]} \\
(\mu \mathrm{MN})\end{array}$ & $\begin{array}{l}\mathrm{C}: \mathrm{N} \\
\text { ratio }\end{array}$ & $\begin{array}{c}\text { Percent } \\
\text { of DON } \\
\text { converted }\end{array}$ \\
\hline \multicolumn{8}{|l|}{ Ammonium } \\
\hline $2.8 \times$ Skidaway River & Aug & nd & nd & 319 & 8.1 & 39 & nd \\
\hline $2.8 \times$ Skidaway River & Feb & $7(4.9)$ & 1.9 & 232 & 5.6 & 42 & 0.9 \\
\hline $28 \times$ Skidaway River & Feb & $60(3)$ & 1.5 & 2352 & 56 & 42 & 0.8 \\
\hline $2.8 \times$ Satilla River Estuary & Oct & $58(3)$ & 1.0 & 2200 & 34 & 65 & 1.2 \\
\hline \multicolumn{8}{|l|}{ Primary amines } \\
\hline $2.8 \times$ Skidaway River & Aug & nd & nd & - & - & - & nd \\
\hline $2.8 \times$ Skidaway River & Feb & nd & nd & - & - & - & nd \\
\hline $28 \times$ Skidaway River & Feb & $41(7.1)$ & 1.0 & - & - & - & 0.5 \\
\hline $2.8 \times$ Satilla River Estuary & Oct & $9(8.5)$ & 0.14 & - & - & - & 0.2 \\
\hline
\end{tabular}


cedure, TDN was measured as nitrate using the nitrate reduction colorimetric technique (Parsons et al. 1992). Nitrate and nitrite concentrations were measured on a Bran Lubbe autoanalyzer using the nitrate reduction technique.

\section{RESULTS}

\section{Biological studies}

The intent of carrying out the bacterial bioassays in a low-nutrient artificial seawater matrix was to decrease background levels of inorganic nitrogen and allow biological detection of nitrogen-rich photoproducts. For studies with the August Skidaway River humic substances, the average initial background concentration of ammonium in the flasks (with added humic substances but without added nitrogen) was high (1.6 $\mu \mathrm{M}$

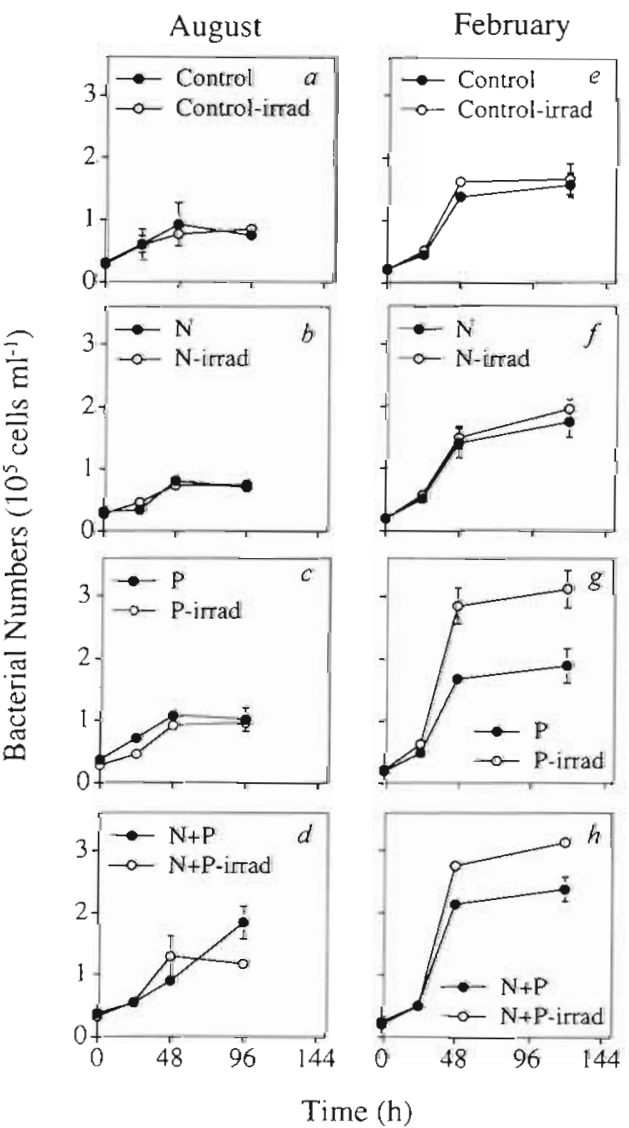

Fig. 1. Bacterial cell numbers in bioassays of humic substances isolated from the Skidaway River in August 1995 and February 1996. Irradiated treatments were exposed to $7 \mathrm{~h}$ of natural sunlight in a quartz vessel dark treatments were foilwrapped during exposure. $\mathrm{N}=$ amended with $16 \mathrm{mM} \mathrm{N}$ as $\mathrm{NH}_{4} \mathrm{NO}_{3} ; \mathrm{P}=$ amended with $1 \mathrm{mM} \mathrm{P}$ as $\mathrm{PO}_{4} ; \mathrm{N}+\mathrm{P}=$ amended with both $N$ and $P$. $(n=3, \pm 1 S D)$ $\pm 0.21 \mathrm{SD}, \mathrm{n}=7$ ), presumably due to unsuccessful removal of ammonium associated with the ingredients used in the artificial seawater matrix. However, in studies with the February Skidaway River humic substances, we successfully decreased the initial concentrations of ammonium in the artificial seawater to $0.08 \mu \mathrm{M}_{\text {; }}$ when humic substances were added, initial ammonium concentrations were $0.40 \mu \mathrm{M}(\mathrm{SD} \pm 0.04$, $\mathrm{n}=4$ ).

During the course of the bioassays, bacterial cell numbers increased 2 -fold or greater over initial levels in all treatments with humic substances collected from the Skidaway River in both August and February. For the August humic substances, irradiation of the control treatment (no added nutrients) had no effect on bacterial growth (Fig. 1a). Likewise, in tredments with adidtions of inorganic nutrients $(N, P, N+P)$, bacterial cell accumulation was not significantly different in irradiated treatments compared to dark treatments (Fig. 1b-d). For the February humic substances, both treatments with $\mathrm{P}$ amendments $(\mathrm{P}, \mathrm{N}+\mathrm{P})$ showed significant enhancement of bacterial cell accumulation in irradiated humic substance treatments relative to dark controls (Mann-Whitney test, $\mathrm{p}<0.05$ ); bacterial cell accumulation was enhanced $41 \%(\mathrm{P})$ and $27 \%(\mathrm{~N}+\mathrm{P})$ in the irradiated treatments. The lack of an irradiation effect on bacterial cell accumulation for the August humic substances suggests that these humic substances contained little or no photolabile components. In contrast, February humic substances contained components that released biologically available products during exposure to natural sunlight. Enhanced cell accumulation was evident in the February study only when the low-nutrient seawater matrix was supplemented with inorganic P (Fig. 1g,h). An exogenous source of inorganic $N$ was not required, however (Fig. 1g), indicating nitrogen sufficiency in the irradiated treatments.

Bacterial utilization of humic substances carbon during the course of the irradiations was calculated from cell accumulation data based on net increases in bacterial cell. carbon between the initial and final time points (assuming a 30\% carbon conversion efficiency). For the August humic substances, carbon utilization under nutrient sufficient conditions accounted for $0.4 \%$ of the original humic carbon for the dark and $0.3 \%$ for the irradiated treatments. For the February humic substances, utilization accounted for $0.9 \%$ of original humic carbon for the dark and $1.2 \%$ for the irradiated treatments.

Instantaneous rates of bacterial protein production were integrated over the course of the bioassays by assuming linear changes in rates between time points. For the August humic substances, irradiation did not stimulate bacterial production over rates measured in 


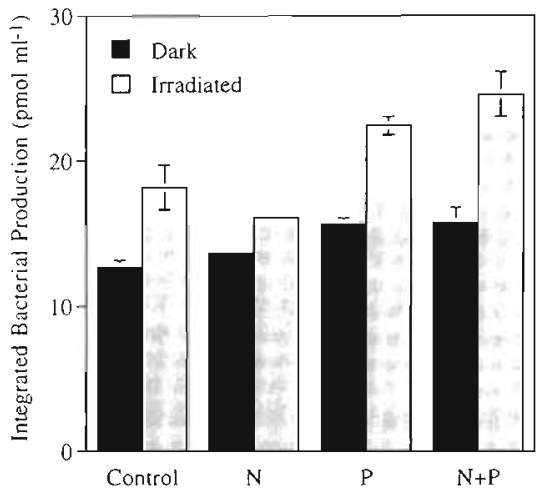

Fig. 2. Bacterial production in a bioassay of humic substances isolated from the Skidaway River in February 1996, expressed as pmol of ${ }^{3} \mathrm{H}$-leucine incorporated into bacterial protein. Instantaneous production rates were integrated over $120 \mathrm{~h}$, with nutrient amendments as described in Fig. $1 \quad(n=3$, $\pm 1 \mathrm{SD})$

dark controls. In fact, production was significantly higher in 2 of the dark treatments relative to the irradiated treatments $(\mathrm{P}, \mathrm{N}+\mathrm{P}$; Mann-Whitney test, $\mathrm{p}<$ 0.05). For the February humic substances, bacterial production was significantly higher in all the irradiated treatments relative to dark treatments (Fig. 2; MannWhitney test, $p<0.05$ ). Enhanced production was greatest in treatments with added $\mathrm{P}$, amounting to a $30 \%(\mathrm{P})$ and $36 \%(\mathrm{~N}+\mathrm{P})$ increase in integrated production over dark controls.

\section{Chemical studies}

Formation of ammonium and dissolved primary amines from photochemical processes was calculated by subtracting concentrations measured in dark controls from those in irradiated samples. For the August Skidaway River humic substances, there were no net increases in ammonium or dissolved primary amines following irradiation. This is consistent with bioassay results, indicating little or no photolabile humic substances in this sample. However, for the February Skidaway River and Satilla River Estuary humic substances, net increases in ammonium were observed (Table 1). Increases in dissolved primary amines were detectable in the more concentrated February Skidaway River sample (28x) and in the Satilla River Estuary sample, but not in the less concentrated February Skidaway River sample.

Photoproduction rates for ammonium and dissolved primary amines were normalized to account for differences among samples with regard to light screening during irradiation and absorbance properties of the DOM. Inconsistencies in light screening (i.e. in the average light exposure during irradiation) arose from differences in DOC concentration and color among the humic substance samples. To correct for the effect of light screening on estimates of photoproduction of ammonium and dissolved primary amines, we calculated the light screening factor using the derivations of Zepp (1982) as follows: $\left(1-e^{-a 350 \times \text { path lengith }}\right) /\left(a_{350} \times\right.$ path length), where path length is the average distance light traveled through the solutions during irradiation in the 2 l quartz flasks (approximately $0.07 \mathrm{~m}$ ). Calculations indicated that rates of formation measured for the February Skidaway River humic substances at $2.8 \times$ concentration were $87 \%$ of those expected with exposure to full sunlight conditions (i.e. with no self-shading within the flask); for the February Skidaway River humic substances at $28 \times$, rates were $24 \%$ of those expected under full sunlight conditions, and for the Satilla River humic substances at $2.8 \times$, rates were $17 \%$ of full sunlight. Rates were adjusted accordingly and then normalized for differences in absorptivity (at $350 \mathrm{~nm} ; \mathrm{a}_{350}$ ) among the humic substance samples by dividing light-screening-corrected rates by $\mathrm{a}_{350}$ (Table 1). Values for $\mathrm{a}_{350}$ were $4.19 \mathrm{~m}^{-1}$ (February Skidaway River $2.8 \times$ ), $57.9 \mathrm{~m}^{-1}$ (February Skidaway River $28 \times$ ), and $86.0 \mathrm{~m}^{-1}$ (Satilla River $2.8 \times$ ).

Although non-normalized rates of ammonium photoproduction varied by as much as 10 -fold among samples, rates normalized to light screening and absorbance properties were more similar (Table 1). Normalized rates of dissolved primary amine photoproduction were likewise more similar than non-normalized, but still varied 4 -fold between the 2 samples in which primary amine photoproduction was detected. Based on DON concentrations in the humic substances, we calculate that 1 to $2 \%$ of the humic-associated $N$ was converted to ammonium plus dissolved primary amines during the $7 \mathrm{~h}$ irradiation (Table 1 ).

\section{DISCUSSION}

DON can be a dominant form of nitrogen in coastal ecosystems, often accounting for up to $50 \%$ of the total $N$ (Sharp 1983). But despite its quantitative importance, the role of DON in the nitrogen cycle of coastal waters is still not well defined, due at least in part to the chemical complexity of the DON pool. Some constituents, such as amino acids, polypeptides, amino sugars, and urea, are readily assimilated by marine microorganisms (Hollibaugh \& Azam 1983, Wheeler \& Kirchman 1986, Coffin 1989, Keil \& Kirchman 1991, Kroer et al. 1994), although they are generally present in low concentrations. Other components, such as humic-associated $\mathrm{N}$ and other unidentified organic nitrogen complexes, are considered much less available but in some cases can serve as an important 
able but in some cases can serve as an important source of nitrogen (Carlsson et al. 1993, Seitzinger \& Sanders 1997). The conversion of humic-associated nitrogen to more labile forms via photochemical alteration would make this latter component of the DON pool even more accessible to marine microorganisms.

The bacterial bioassays used in this study provided a mechanism to measure all biologically available nitrogen photoproducts, including compounds that may not be captured by analytical measurements of a limited suite of compounds. Other possible nitrogen-rich photoproducts include nitrate, nitrite, and urea, as well as unidentified but photochemically modified nitrogen that remains physically associated with humic substances (Carlsson \& Granéli 1993). Total biologically avallable nutrogen in the February Skidaway River humic substance bioassay was estimated to be $0.57 \mu \mathrm{M}$ $N( \pm 0.06)$ in the irradiated ( $P$ treatment), based on measurements of net bacterial biomass accumulation and assuming a $\mathrm{C}: \mathrm{N}$ ratio of $4: 1$ (Tuomi et al. 1995). If bacterial growth in the dark treatments was $\mathrm{N}$ limited (bacterial growth data suggest both $\mathrm{N}$ and $\mathrm{P}$ limitation; Fig. $1 \mathrm{~g}$ ), then total bacterial utilization of nitrogen without irradiation was $0.33 \mu \mathrm{MN}( \pm 0.05)$. Thus irradiation with natural sunlight resulted in the conversion of $0.24 \mu \mathrm{MN}$ into biologically labile forms. Chemical analyses of this same sample indicated that photochemical production of ammonium plus dissolved primary amines accounted for $0.08 \mu \mathrm{M} N$, or approximately one-third of the calculated increase in available nitrogen following irradiation of the DOM. The remaining two-thirds may be other small identifiable compounds or complex but photochemically modified compounds, including humic substances (Miller \& Moran 1997). Together, these biologically labile nitrogen products (ammonium, dissolved primary amines, and not-yet-identified compounds) accounted for up to $6 \%$ of the total nitrogen in these humic substances.

Primary amines released from humic substances by exposure to sunlight may be derived from amino acids that are chemically or physically associated with humic substances (Sharp 1983, Hubberten 1994, Hubberten et al. 1995). Glycine, aspartic acid, glutamic acid, alanine, and serine have been found to be associated with marine humic substances and ultrafiltered marine DOM (Gagosian \& Stuermer 1977, Malcolm 1990. Hubberten et al. 1995, McCarthy et al. 1996). Alternatively, proteinaceous material such as enzymes that are physically complexed to humic substances (Wetzel 1991) may be a source of the dissolved primary amine photoproducts. The mechanism for the photochemical production of ammonium from humic substances is likewise not clearly understood (Bushaw et al. 1996).

We found no evidence for the photochemical formation of labile $N$ in 1 of 3 humic substance samples
(August Skidaway River). The high background ammonium concentrations in this sample would have limited our ability to measure nitrogen photoproducts in the bacterial bioassays, yet there was also no evidence of labile carbon photoproducts from these humic substances (Figs. 1 \& 2). Chemical analyses of ammonium and dissolved primary amines likewise indicated a lack of photolability of the DOM in this sample (Table 1). Significant temporal variations in the photoreactivity of DOM have been reported previously for a number of ecosystems (Strome \& Miller 1978, Stewart \& Wetzel 1980, Bushaw et al. 1996). In some of these cases, DOM has been found to be less photoreactive in mid to late summer compared to earlier in the year, possibly reflecting the bleaching of photoreactive compounds throuyh lime or seasonal differences in sources of DOM. Exposure to natural sunlight has been found to actually decrease the biological availability of organic matter to bacteria in some cases (Keil \& Kirchman 1994, Tranvik \& Kokalj 1998, Pausz \& Herndl 1999), although this has not yet been shown for humic substances.

Our studies indicate a mechanism whereby the humic substances component of marine DON, generally considered of limited biologically availability, can be converted to more available forms. Not all samples of humic substance-associated DON produced labile photoproducts, however, and the kinetics of photoproduct formation with increasing exposure to sunlight are not yet known, indicating the need for a better understanding of this process. On a regional scale, our results imply that DON may play a larger role in nitrogen cycling in coastal waters of the southeastern U.S. than previously considered (Bishop et al. 1984, Hanson et al. 1990). We calculate that exports of terrestrially derived DON to this region are approximately $49 \times 10^{3} \mathrm{t} N$ annually (based on an estimated annual export of $1200 \times 10^{3} \mathrm{t}$ DOC and a C: $N$ ratio of 24.5; Alberts \& Filip 1994, Moran \& Hodson 1994), and about $20 \%$ of the exported DON is in the form of humic substance-associated nitrogen. Photoproduction of biologically active nitrogen from humic substances and other recalcitrant forms of organic matter may have important implications for primary and secondary production in other coastal environments as well, particularly when nitrogen is the macronutrient most limiting to biological productivity.

Acknowledgements. We thank Richard Zepp for suggestions on experimental design and analysis, Deborah Bronk and Merryl Alber for use of laboratory equipment, and Wenying Ye, Andrew Newton, and Wade Sheldon for assistance in the laboratory and field. The National UV Monitoring Center at the University of Georgia provided irradiance data. This research was supported by the Georgia River LMER project (NSF Land Margin Ecosystems Research Program; DEB9412089) and by the U.S. EPA. 


\section{LITERATURE CITED}

Aiken GR (1985) Isolation and concentration techniques for aquatic humic substances. In: Aiken GR, McKnight DM, Wershaw RL, MacCarthy P (eds) Humic substances in soil, sediment and water. Wiley, Chichester, p 363-385

Alberts JJ, Filip Z (1994) Humic substances in rivers and estuaries of Georgia, USA. Trends Chem Geol 1:143-162

Amador JA, Alexander M, Zika RG (1989) Sequential photochemical and microbial degradation of organic molecules bound to humic acid. Appl Environ Microbiol 55:2843-2849

Armstrong FAJ, Tibbitts S (1968) Photochemical combustion of organic matter in seawater, for nitrogen, phosphorus, and carbon determination. J Mar Biol Assoc UK 48:143-152

Bauer JE, Williams PM, Druffel ERM (1992) C-14 activity of dissolved organic carbon fractions in the north-central Pacific and Sargasso Sea. Nature 357:667-670

Bishop SS, Emmanuele KA, Yoder JA (1984) Nutrient limitation of phytoplankton growth in Georgia nearshore waters. Estuaries 7:506-512

Bronk DA, Glibert PM, Malone TC, Banahan S, Sahlsten E (1998) Inorganic and organic nitrogen cycling in Chesapeake Bay: autotrophic versus heterotrophic processes and relationships to carbon flux. Aquat Microb Ecol 15: $177-189$

Bushaw KL, Zepp RG, Tarr MA, Schulz-Jander D, Bourbonniere RA, Hodson RE, Miller WL, Bronk DA, Moran MA. (1996) Photochemical release of biologically labile nitrogen from aquatic dissolved organic matter. Nature 381 $404-407$

Carlsson P, Granéli E (1993) Availability of humic bound nitrogen for coastal phytoplankton. Estuar Coast Shelf Sci $36: 433-447$

Carlsson P, Segatto AZ, Granéli E (1993) Nitrogen bound to humic matter of terrestrial origin - a nitrogen pool for coastal phytoplankton? Mar Ecol Prog Ser 97:105-116

Carlsson P, Granéli E, Tester P, Boni L (1995) Influence of riverine humic substance on bacteria, protozoa, phytoplankton, and copepods in a coastal plankton community. Mar Ecol Prog Ser 127:213-221

Coffin RB (1989) Bacterial uptake of dissolved free and combined amino acids in estuarine waters. Limnol Oceanogr $34: 531-542$

Gagosian RB, Stuermer DH (1977) The cycling of biogenic compounds and their diagenetically transformed products in seawater. Mar Chem 5:605-632

Gardener WS, Cavaletto JF, Bootsma HA, Lavrentyev PJ, Troncone F (1998) Nitrogen cycling rates and light effects in tropical Lake Maracaibo, Venezuela. Limnol Oceanogr 43:1814-1825

Grasshoff K, Ehrhardt E, Kremling K (1983) Methods of seawater analysis. Verlag Chemie, Weinheim

Hanson RB, Robertson CY, Yoder JA, Verity PG, Bishop SS (1990) Nitrogen recycling in coastal waters of southeastern U.S. during summer 1986. J Mar Res 48:641-660

Harrison PJ, Waters RE, Taylor FJR (1980) A broad spectrum artificial seawater medium for coastal and open ocean phytoplankton. J Phycol 16:28-35

Hobbie JE, Daley RJ, Jasper S (1977) Use of Nuclepore filters for counting bacteria by epifluorescence microscopy. Appl Environ Microbiol 33:1225-1228

Hollibaugh JT, Azam F (1983) Microbial degradation of dissolved proteins in seawater Limnol Oceanogr 28 : $1104-1116$

Hubberten U (1994) Amino-acid composition of seawater and dissolved humic substances in the Greenland Sea. Mar Chem 45:187-196
Hubberten U, Lara RJ, Kattner G (1995) Refractory organic compounds in polar waters: relationships between humic substances and amino acids in the Arctic and Antarctic. J Mar Res 53:137-149

Jørgensen NOG, Tranvik L, Edling H, Granéli W, Lindell M (1998) Effects of sunlight on occurrence and bacterial turnover of specific carbon and nitrogen compounds in lake water. FEMS Microbiol Ecol 25:217-227

Keil RG, Kirchman DL (1991) Contribution of dissolved free amino acids and ammonium to the nitrogen requirements of heterotrophic bacterioplankton. Mar Ecol Prog Ser 73 $1-10$

Keil RG, Kirchman DL (1994) Abiotic transformation of labile protein to refractory protein in sea water. Mar Chem 45 $187-196$

Kroer N, Jørgensen NOG, Coffin RB (1994) Utilization of dissolved nitrogen by heterotrophic bacterioplankton: a comparison of three ecosystems. Appl Environ Microbiol 60: 4116-4123

Leenheer JA (1981) Comprehensive approach to preparative isolation and fractionation of dissolved organic carbon from natural waters and wastewaters. Environ Sci Tech $15: 578-587$

Malcolm RL (1990) The uniqueness of humic substances in each of soil, stream and marine environments. Anal Chem Acta 232:19-30

McCarthy M, Hedges J, Benner R (1996) Major biochemical composition of dissolved high molecular weight organic matter in seawater. Mar Chem 55:281-297

Meyers-Schulte KJ, Hedges JI (1986) Molecular evidence for a terrestrial component of organic matter dissolved in ocean water. Nature 321:61-63

Miller WL, Moran MA (1997) Interaction of photochemical and microbial processes in the degradation of refractory dissolved organic matter from a coastal marine environment. Limnol Oceanogr 42:1317-1324

Miller WL, Zepp RG (1995) Photochemical production of dissolved inorganic carbon from terrestrial organic matter: significance to the oceanic organic carbon cycle. Geophys Res Lett 22:417-420

Moran MA, Hodson RE (1990) Bacterial production on humic and nonhumic components of dissolved organic carbon. Limnol Oceanogr 35:1744-1756

Moran MA, Hodson RE (1994) Support of bacterioplankton production by dissolved humic substances from three marine environments. Mar Ecol Prog Ser 110:241-247

Moran MA, Zepp RG (1997) Photochemical formation of biologically labile compounds from dissolved organic matter. Limnol Oceanogr 42:1307-1316

Moran MA, Pomeroy LR, Sheppard ES, Atkinson LP. Hodson RE (1991) Distribution of terrestrially derived dissolved organic matter on the southeastern U.S. continental shelf. Limnol Oceanogr 36:1134-1149

Parsons TR, Maita Y, Lalli CM (1992) A manual of chemical and biological methods for seawater analysis. Pergamon Press, Oxford

Pausz C, Herndl GJ (1999) Role of ultraviolet radiation on phytoplankton extracellular release and its subsequent utilization by marine bacterioplankton. Aquat Microb Ecol 18:85-93

Seitzinger SP, Sanders RW (1997) Contribution of dissolved organic nitrogen from rivers to estuarine eutrophication. Mar Ecol Prog Ser 159:1-12

Sharp JH (1983) The distributions of inorganic nitrogen and dissolved and particulate nitrogen in the sea. In: Carpenter EJ, Capone DG (eds) Nitrogen in the marine environment. Academic Press, New York, p 1-35 
Smith J, Azam F (1992) A simple, economical method for measuring bacterial protein synthesis rates in seawater using ${ }^{3} \mathrm{H}$-leucine. Mar Microb Food Webs 6:107-114

Stewart AJ, Wetzel RG (1980) Asymmetrical relationships between fluorescence, absorbance and dissolved organic carbon. Limnol Oceanogr 26:590-597

Strome DJ, Miller MC (1978) Photolytic changes in dissolved humic substances. Int Ver Theor Angew Limnol Verh 20 : $1248-1254$

Thurman EM (1985) Organic geochemistry of natural waters. Nijhoff/Junk, Dordrecht

Tranvik L, Kokalj S (1998) Decreased biodegradability of algal DOC due to interactive effects of UV radiation and humic matter. Aquat Microb Ecol 14:301-307

Tuomi P, Fagerbakke KM, Bratbak G, Heldal M (1995) Nutritional enrichment of a microbial community: the effects on activity, elemental composition, community

Editorial responsibility: Bess Ward,

Princeton, New Jersey, USA structure and virus production. FEMS Microbiol Ecol 16 $123-134$

Wetzel RG (1991) Extracellular enzymatic interactions: storage, redistribution, and interspecific communication. In: Chróst RJ (ed) Microbial enzymes in aquatic environments. Springer-Verlag, New York, p 6-28

Wheeler PA, Kirchman DL (1986) Utilization of inorganic and organic nitrogen by bacteria in marine systems. Limnol Oceanogr 31:998-1009

Zepp RG (1982) Experimental approaches to environmental photochemistry. In: Hutzinger BO (ed) The handbook of environmental chemistry, Vol 2, Part B. Springer-Verlag, Berlin, p 19-41

Zepp RG, Schlotzhauer PF (1981) Comparison of photochemical behavior of various humic substances in water: III. Spectroscopic properties of humic substances. Chemosphere 10:479

Submitted: June 16, 1998; Accopted: December 28, 1998 Proofs received from author(s): July 27, 1999 